\title{
Local knowledge of the Bornean Peacock-pheasant: a reply to Sözer et al. (2000)
}

\author{
M. KINNAIRD and T. O'BRIEN
}

We thank Sözer et al. (2000) for paying such close attention to our paper and taking the time to express their opinion so extensively. Sözer et al. express the opinion that our questionnaire and treatment of the data were biased. They objected to our request for assistance that accompanied the questionnaire, the use of pictures of unequal size, the wording of most questions, and what they considered a flawed semi-structured interview. Finally, they question the ability of the Kalimantan people to comprehend the interview process and respond accurately. They conclude a long discussion of the semi-structured interview with the comment "the data presented by O'Brien et al. (1999) are not incontro-

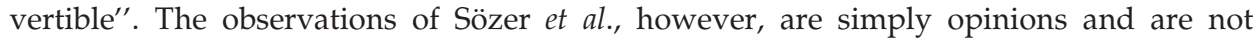
backed by data or supporting arguments. Our opinions differ, and we do not find their arguments compelling. We have not presented our study as incontrovertible, and have in fact discussed the limitations of our survey at length in the manuscript.

We disagree with the premise that the survey technique was biased. Anthropologists and biologists, including researchers from WWF, CIFOR, TROPENBOS, and Rutgers University, often use picture books and field guides in interviews with various Dyak groups in Kalimantan and none report problems of scale or ambiguity in identifying species (i.e. people have no trouble distinguishing between a small forest kingfisher and a large galliform even though scale varies in the plates). The survey and the request for assistance were screened beforehand by a number of Indonesian colleagues in order to catch ambiguities. Sözer et al.'s translation of our request for assistance is too literal and makes it appear naive. The interviewers were present when most, if not all, respondents filled out the written questionnaire, and they conducted the semi-structured interviews as conversations during which a series of questions were to be answered. I. Setiawan and A. Setiadi (junior authors on Sözer et al. 2000) conducted the first half of the interview and N. Winarni and A. Setiadi conducted the second half of the survey. Neither survey team reported problems with the interview process (bias, confusion, ambiguity) beyond what we discuss in our paper. If there had been a systematic problem, as implied by Sözer et al., we are certain that the interview staff would have reported it. To withhold knowledge of problems with the interview would call into question the professional competency of the interview teams.

A number of opinions expressed by Sözer et al. are supported by personal 
observations and unpublished data, presumably of Sözer, who has worked on and off in Kalimantan for several years. It is extremely difficult to argue against hidden information. For instance, Sözer's claim that Bulwar's pheasant is "a fairly common and conspicuous species" conflicts with the observations of our survey in central Kalimantan, and of surveys conducted on four occasions in east Kalimantan by WCS and CIFOR. Obviously, our experiences in Kalimantan have been different. We therefore urge Sözer et al. to publish their data. So little is known about Kalimantan pheasants that every detail will be well received in ornithological journals.

\section{References}

O'Brien, T.G., Winardi, N.K., Saanin, F.M., Kinnaird, M.F. and Jepson, P. (1999) Distribution and conservation status of Bornean Peacock-pheasant Polyplectron schleiermacheri in Central Kalimantan, Indonesia. Bird Conserv. Internatn. 9: 373-385.

Sözer, R., Setiawan, I. and Setiadi, A.P. (2000). Local knowledge of the Bornean Peacockpheasant Polyplectron schleiermacheri: a critique of O'Brien et al. (1998a). Bird Conserv. Internatn. 10: 311-316.

M. KINNAIRD and T. O'BRIEN

Wildlife Conservation Society-IP, P.O. Box 311, JI Ciremei No. 8 Bogor 16003, Indonesia (E-mail wcs-ip@pop.indo.net.id) 